\title{
DO PRESENTE AO PASSADO: A representação da memória em Confissão de Leontina
}

From the present to the past: representation of the memory in Confissão de Leontina

Francisco Brunno Carvalho Reis ${ }^{1}$

Silvana Maria Pantoja dos Santos ${ }^{2}$

RESUMO: Este trabalho teve por objetivo investigar a representação da memória no conto Confissão de Leontina (1988), de Lygia Fagundes Telles. A obra narra a história de Leontina, personagem principal, que descreve sua vida pretérita, bem como suas angústias e cicatrizes deixadas pela sociedade da qual fazia parte. Para tanto, a protagonista rememora acontecimentos marcantes de sua vida, uma vez que ela era uma meretriz, apresentando os traumas decorrentes de um meio social marcado pela exclusão social. Percebeu-se, por meio do discurso da personagem, a presença de mecanismos ligados à memória, os quais foram investigados neste trabalho, tais como a memória individual e coletiva articuladas à percepção. Desse modo, utilizou-se como referencial teórico: Bergson (1999), Halbwachs (2003), Le Goff (1990), dentre outros.

Palavras-chave: Memória. Percepção. Lygia Fagundes Telles.

ABSTRACT: This study had the purpose to investigate the memories representations in the tale Confissão de Leontina (1988), written by Lygia Fagundes Telles. The work tells the history of Leontina, main character, who describes her past life, as well as her anguish and scars left by the society which she was part. Therefore, the protagonist remembers important happenings of her life, once she was prostitute, presenting traumas due from a social medium marked by the social exclusion. It was perceived, through the character discourse, the presence of mechanisms linked to the memory, which were investigated in this work, such as the personal and collective articulated to the perception. Thus, it was used as theoretical reference: Bergson (1999), Halbwachs (2003), Le Goff (1990), among others.

Keywords: Memory. Perception. Lygia Fagundes Telles.

\footnotetext{
${ }^{1}$ Mestre em Literatura (UESPI). Graduado em Letras-Português e Literatura de Língua Portuguesa (UFPI). E-mail: f.brunno20@hotmail.com

2 Doutora em Teoria Literária (UFPE). Professora do Mestrado em Letras (UEMA) e Mestrado em Letras (UESPI). E-mail: silvanapantoja3@gmail.com
} 


\section{INTRODUÇÃO}

A memória tem a finalidade de resgatar, mesmo que de forma fragmentada, o que ocorreu com determinada pessoa em épocas pretéritas da sua existência. $A$ memória se volta a situações que ocorreram em um passado, de maneira que as lembranças deixam marcas no repertório de vida dos indivíduos (LE GOFF, 1990). Desse modo, de uma forma ou de outra, as pessoas vão rememorá-las à medida que trazem à tona manifestações que até então estavam esquecidas, ou, temporariamente, silenciadas. Os eventos memorialísticos têm, portanto, como característica a conservação, sendo, assim, atualizados no processo de recordação.

Sobre esse aspecto, menciona Pollak (2010, p. 45) "quando falo em construção, em nível individual, quero dizer que os modos de construção podem ser tanto conscientes como inconscientes". A memória tem o caráter de selecionar acontecimentos vividos individualmente ou no seio de um grupo, nos mais diversos contextos em que se está inserido. As recordações que emergem são escolhidas, de alguma forma, pela memória, pois o cérebro não teria capacidade suficiente de internalizar todos os episódios pretéritos ocorridos na vida do sujeito que lembra.

É com base nesses argumentos que o presente trabalho visa investigar como a memória está presente no conto Confissão de Leontina (1988), da escritora Lygia Fagundes Telles. Para tanto, busca-se refletir de que forma as recordações, na presença do vivido, manifestam-se na figura da personagem protagonista do conto, Leontina.

A personagem principal que sofreu muito em sua vida. Perdeu a mãe, a irmã morreu, ainda era pequena e, seu único parente, seu primo, Pedro, a renega porque ele se torna médico e ascende socialmente, passa não a querer como parente. $O$ discurso da protagonista é marcado pela dor, pelas cicatrizes que a vida lhe impôs. Leontina foi presa por ter sido acusada de um crime de assassinato a um senhor de idade muito poderoso.

Diante disso, a personagem principal narra o que se passou pela sua vida, caracterizando seu relato como confessional, isto é, ela faz declarações e juízos de valor a respeito dos atos que the foram marcantes e que serviram de base para o seu condicionamento social presente. 


\section{MEMÓRIA: DESIGNAÇÕES E COMPLEXIDADES}

A temática da memória faz-se presente na literatura na presença dos personagens, pois através dos seus comportamentos, eles se voltam ao passado, seja para viver acontecimentos que Ihe marcaram de forma positiva ou negativa, seja para recordar situações em que o sujeito participou, e por algum motivo, tais situações são rememoradas por este.

É por meio de acontecimentos evocados, que, no momento oportuno, eles emergem. De fato, os personagens, ao se pronunciarem sobre determinado acontecimento vivido, são eles mesmos fruto e criação deste.

Sobre o referido assunto, Iziquierdo afirma:

O nosso passado, nossas memórias, nossos esquecimentos voluntários, não só nos dizem quem somos, mas também nos permitem projetar rumo ao futuro; isto é, nos dizem quem poderemos ser. O passado contém o acervo de dados, o único que possuímos, o tesouro que nos permite traçar linhas a partir dele, atravessando o efêmero presente em que vivemos, rumo ao futuro (IZIQUIERDO, 2002, p. 01)

Desse modo, o sujeito não consegue se esquecer do passado completamente. As lembranças boas que provocaram sensações agradáveis, bem como aquelas que despertaram sentimentos ruins e, com estes, a perda, o sofrimento e as cicatrizes reverberam, de algum modo, no comportamento dos indivíduos, mais especificamente, dos personagens. As situações a que toda hora o sujeito é remetido, não deixa de ser um aprendizado de relações e experiências que o mesmo vem a adquirir posteriormente.

Geralmente as memórias remetem a ocasiões vividas pelo indivíduo e servem para serem relembradas. Elas podem surgir, no processo de recordação, de forma fragmentada, isto é, as lembranças são múltiplas, pois são formadas por encadeamentos de vários tipos de acontecimentos que somando-se estes, tem-se a ideia do todo recordado, isto é, do processo completo de rememoração (RICOUER, 2007). 
Uma vez que existe a diferença entre recordação e lembrança, esta tem caráter abrangente devido à possiblidade, na sua origem, de vários acontecimentos lembrados se juntarem, cujos resultados são amalgamados por meio da multiplicidade eventos ocorridos envolvimento na cena lembrada. Já a recordação é de caráter estático, pois para se obter esta, busca o fato de amplitude singular, o que se manifesta na intersecção entre a lembrança e sua chegada ao indivíduo, o que é particular e que não pode ser, jamais, esquecido. Naquela forma de memória, há apenas um fato a ser rememorado, tido este, como matriz no processo de resgate da memória (RICOUER, 2007).

Ricouer (2007) afirma que a memória ainda se vale de estados de coisas, isto é, a lembrança se torna geral, através de um fato especificamente vivido que, em quaisquer circunstâncias, tem-se a plena convicção que ele aconteceu na presença do grupo social que presenciou o episódio pretérito. Essas lembranças são classificadas como estados de coisas por possuir como características fixas, imutáveis, pois as mesmas estão delimitadas no tempo e servem como referência de um grupo social específico. Desse modo, o grupo vai se remeter a um ocorrido de forma homogênea e única tendo seu ponto específico o referido acontecimento lembrado.

O estado de coisas é o fio condutor que liga a lembrança à recordação, as ocasiões imutáveis daquela são formadas de fragmentos que as ordenam e se manifestam na presença de fatos singulares, estes vêm à tona como eleitos depois de uma prévia seleção de lembranças e estão gravados na memória do indivíduo (RICOUER, 2007).

Essa configuração do recordar da memória é tida por meio das recordações, porque só se consegue voltar ao tempo por meio delas, quando se tem a plena conviç̧ão de que o ocorrido, realmente, realizou-se em uma situação pretérita.

E aquilo que foi impresso, nós o recordamos e o sabemos, enquanto a sua imagem está ali, ao passo que aquilo que é apagado, ou aquilo que não foi capaz de ser impresso, nós o esquecemos, isto é, não o sabemos (RICOUER, 2007, p. 28).

No que tange aos aspectos rememorados, só se consegue despertar ou absorver determinado fato quando este é vivido. Os processos de rememoração se valem das imagens para solidificar o que se passou. Estas servem para deixar 
registrado o acontecido, funcionam como a prova substancial representada como reflexo e tradução do acontecimento que se passou na vida de determinada pessoa.

Fato parecido ocorre no conto Confissão de Leontina em que as imagens vêm à memória da personagem principal da forma que a mesma as viveu e ela transforma tais imagens em retrato, pois as recordações estão instaladas neste local, ficando as impressões, imortalizadas na sua consciência de narradora, cuja materialização é o próprio relato da personagem.

Os acontecimentos podem ser reforçados por participantes de uma ação que estão, no passado, conjuntamente com o sujeito que rememora. Para essa situação, dá-se o nome de memória coletiva que, às vezes, pauta-se na força dos grupos para a preservação e conservação da memória bem como para a rememoração dos acontecimentos, o que, por sua vez, se opõe, sobremaneira, à memória individual que possui caráter específico e pertencente a um único indivíduo (BERGSON, p. 1999). Essas duas memórias podem transcender à noção de memória histórica, em uma análise, ao se portarem ao processo de aquisição do pretérito e na desenvoltura de como este vem a ser lembrado.

\subsection{As interligações: cadeia entre memória individual e coletiva}

O sujeito, através de suas recordações, revive momentos que aconteceram em sua vida, porém as memórias podem ser aguçadas, ou não, por meio dos participantes da cena enunciada. Um indivíduo, ao lembrar-se de um determinado fato, em que o mesmo por algum acaso venha a ter participado, e que, neste acontecimento, ele não se lembre mais de nenhum participante envolvido, apenas dele próprio, o que será recordado é fruto de sua única memória. Assim, sobre essa memória individual, Bergson descreve:

As coisas se estabelecem, ao contrário, se partimos da própria representação, isto é, da totalidade das imagens percebidas. Minha percepção, em estado puro e isolado de minha memória, não vai de meu corpo aos outros corpos: ela está no conjunto dos corpos em primeiro lugar, depois aos poucos se limita e adota meu corpo por centro (BERGSON, 1999, p. 63).

Eis o que, no processo de percepção, para a recordação dos fatos, manifestase, especialmente, através da percepção individual, isto é, esta, mantendo-se em 
contato com o ambiente, com as circunstâncias pelas quais se deu a recordação, o indivíduo, inserido em tal ação e, participando da mesma, tem a facilidade de se transferir à cena pretérita que o mesmo participou. A memória individual, por meio do corpo, bem como da percepção, não se porta a outros participantes que por acaso tenham vindo participar, resta-se, assim, apenas a memória do indivíduo que se materializa, singularmente, no processo de rememoração do que o vivido, de fato, venha a representar.

Dessa forma, o acontecimento vivido é recordado por meio de imagens, uma vez que esta é a concretização das rememorações. Os fatos pretéritos estão gravados na memória por meio de imagens, estas, por sua vez, asseguram que aquelas venham a ser preservadas na memória do sujeito que lembra.

As imagens que nos cercam parecerão voltar-se em direção a nosso corpo, mas desta vez iluminada a face que o interessa; elas destacarão de sua substância o que tivermos retido de passagem, o que somos capazes de influenciar. Indiferentes umas às outras em razão do mecanismo radical que as vincula, elas apresentam reciprocamente, umas às outras, todas as suas faces ao mesmo tempo, o que equivale a dizer que elas agem e reagem entre si por todas as suas partes elementares e, que, consequentemente, nenhuma delas é percebida nem se percebe conscientemente (BERGSON, 1999, p. 34).

As imagens têm o poder de relembrar cenas que ocorreram em um passado memorial, isto é, elas conservam o que ficou de marcas registradas, do qual o corpo participou por meio dos fatos vividos. Elas filtram os acontecimentos, de modo que as mesmas impregnam o que é vivido como "gravuras" na memória. Os momentos que elas descrevem são percebidos inconscientemente, isto é, as lembranças descritas podem aparecer de maneira espontânea através do corpo, o que ocasiona à individualidade, porém, ao existir mais participantes na ação descrita, eles reforçam à ocasião que estar sendo rememorada por meio destes o que reforça o caráter do que é rememorado.

A esses outros sujeitos que passam, por ventura, a integrar o momento vivido, junto a aquele que enuncia, e que podem ajudar na rememoração dos fatos, passa a fazer parte da memória coletiva. Esta, portanto, se pauta na importância que o grupo desempenha no fortalecimento das memórias a serem recordadas. A respeito disso, Halbwachs comenta: 
Se quisesse reconstituir em sua integridade a lembrança de tal acontecimento, seria preciso que eu juntasse todas as reproduções deformadas e parciais de que ela é objeto entre todos os membros do grupo. Ao contrário, minhas lembranças pessoais são inteiramente minhas, estão inteiras em mim (HALBWACHS, 2003, p. 73).

Para que se forme o todo dos acontecimentos recordados, ou pelos menos a junção destes, é preciso que mais de um sujeito tenha vivenciado o cenário, em tempo simultâneo, junto com o participante que rememora. Eles, em grupo, vão recordar de aspectos diferenciados, ou seja, às vezes determinado acontecimento passou despercebido pelo sujeito que fala, mas o outro sujeito que rememora não deixou passar tal ação, recordando-a. Dessa forma, em um diálogo, por exemplo, os fatos reatados por ambos podem se agrupar de modo que o vivido seja, possivelmente, formado (HALBWACHS, 2003).

É o que ocorre, por exemplo, no conto Confissão de Leontina em que a personagem revive suas cicatrizes através das suas memórias e das memórias de outros sujeitos que, de maneira interessante, conviveram com a protagonista da estória.

\subsection{As dores e as cicatrizes de Leontina: recordar para viver}

O conto Confissão de Leontina trata-se da volta ao passado por meio de uma reflexão sobre a identidade da narradora que há muito foi perdida. Como Bergson (1999) afirma, os acontecimentos se dão de forma direta. O tempo não retorna, mas segue um fluxo contínuo, e junto a este, as memórias o acompanham. Passado e memória são, simultaneamente, ressurgidos, podendo ser rememorados e revividos no relato da personagem principal do conto, cujo depoimento se dá em ordem crescente no que diz respeito ao transcorrer de sua vida, até o ápice da injustiça que Ihe fora cometida.

A protagonista foi refém da vida que lhe outorgou seu destino. Ela, portanto, é marcada pelos acontecimentos que Ihe sucederam. Diz a protagonista: "Já contei esta história tantas vezes e ninguém quis me acreditar. Vou agora contar tudo especialmente para a senhora que se não pode me ajudar pelo menos não fica me atormentando como fazem os outros" (TELLES, 1988, p. 87). A personagem aborda 
o fato que mudou o destino de sua vida, e rememora-o, por meio da volta ao passado de sua vida que dá a perceber que faz parte de um possível interrogatório, uma vez que a mesma se encontra presa, por ter sido acusada de ter cometido um crime. Ela, ainda, não se sente disposta para relembrar essas cenas traumáticas de sua vida pretérita.

Dessa forma, pode-se ver que Leontina vive em estado de melancolia, pois a mesma não consegue se livrar do fato que mudou os rumos de sua história. Quando não se consegue libertar de episódios dolorosos, o personagem vive em estado de melancolia (FREUD, 2010).

Sobre o tema melancolia, pode-se ver nessa passagem do texto: "Seu Armando que é pianista lá do salão de danças já me aconselhou a não perder a calma e esperar com confiança que a justiça pode tardar, mas um dia vem" (TELLES, 1988, p. 87). O que se percebe pelo relato da protagonista, é que esse ocorrido não sai de sua cabeça, vê-se a personagem constantemente atormentada pelo mesmo. Isso porque a protagonista nutre esperança de sair da prisão e ser inocentada pelo crime que a mesma não cometera. Ela agiu em legítima defesa por ter sido espancada por um senhor de idade que, possivelmente, queria obrigá-la a fazer sexo com ele.

Leontina relata o constrangimento e vergonha passados no ato da prisão e calúnia que ela sofrera. Pelo que é relatado, pelo teor das cicatrizes que esse fato deixou na personagem, pode-se classificar que o estado em que a mesma se encontra é traumático, uma vez que ela é marcada pela dor e sofrimento que a acompanham vida a fora. Sobre o trauma da protagonista, veja-se:

O bofetão veio nessa hora e foi tão forte que quase me fez cair no banco. Meu ouvido zumbiu e minha cara ardeu fogo. Eu chorava, chorava pedindo ajuda da minha mãe como sempre fiz nas aperturas. O outro bofetão me fez bater com a cabeça na porta e a cabeça rachou feito coco. Apertei a cabeça na mão e pensei inda no Rogério que um dia surrou um cara só porque ele esbarrou de propósito no meu peito. Agora eu estava apanhando que nem a pior das vagabundas (TELLES, 1985, p. 116).

A prisão, sob a alegação de um crime, é o fator preponderante da vida traumática da personagem, pois se percebe que ela não consegue se desligar desse ato que mudou os rumos de seu futuro. Soma-se a isso, o fato de ela ter uma profissão sem relevância social para a sociedade, além do descrédito do seu relato, 
devido à importância econômica que o defunto possuía no meio social. Sobre o trauma, Levi descreve:

O melhor modo para defender-se das invasões das memórias difíceis é impedir seu ingresso, estender um cordão sanitário ao longo do limite. É mais fácil vetar o ingresso de uma recordação do que dela se livrar depois que foi registrada (LEVI, 1990, p. 14).

Percebe-se, pelo comentário da protagonista, ao longo da história, que a mesma não está liberta dos episódios marcantes de sua existência e que, por mais que a figura feminina tente se livrar deles, estes já fazem parte de sua vida futura.

Devido à sua dor e seu rememorar das principais cenas dos fatos recordados, pode-se vislumbrar, em Confissão de Leontina, a memória individual, uma vez que o sujeito que se enuncia relata seus fatos ocorridos. O foco da ação no conto são as recordações que a protagonista coloca como papel primário de sua vida. Ao se portar às situações pretéritas, tem-se a recordação que a personagem faz dela própria.

Sobre a memória individual, veja-se:

Minha mãe vivia lavando roupa na beirada lagoa. Ela lavava quase toda a roupa da gente da vila, mas não se queixava. Nunca vi minha mãe se queixar. Era miudinha e tão magra que até hoje fico pensando como ela ia buscar força para trabalhar tanto (TELLES, 1985, p. 88).

As cenas que Leontina lembra são particulares, isto é, o que é lembrado faz parte somente de seu passado, e ela os evoca no seu discurso após muito tempo, somente a personagem faz parte da enunciação. São deixados rastros, nos comentários, de impressões e discussões pessoais dela em relação ao vivido.

Leontina ao recordar esse fato ocorrido com sua mãe, ela se coloca na cena, ou seja, ela se utiliza de imagens que colaboram para que se possa reviver o episódio da mãe lavando roupa. Bergson (1999, p.17) afirma que "chamo de matéria o conjunto de imagens, e de percepção da matéria essas mesmas imagens relacionadas à ação possível de uma certa imagem determinada, meu corpo". As imagens possuem o poder de materializar as lembranças que estão impregnadas na memória por meio do armazenamento das "gravuras" vividas e recordadas. A matéria diz respeito ao meio o qual estar se processando a ação, porque só se 
recorda daquilo que de fato está presente no ato de recordar, por meio da inserção do corpo do sujeito, pois este é o que permite o ensejo da memória, pois só se rememora o que ele é capaz de guardar, por intermédio do espaço no qual está inserido.

Outra categoria elucidada por Bergson (1999) é a percepção, esta é tida quando o sujeito que enuncia faz parte dos acontecimentos que estão na sua lembrança, através do envolvimento direto com seu corpo. Isso é concretizado na seguinte passagem em Confissão de Leontina (TELLES, 1985, p.89) "eu fazia comida e cuidava de casa. Minha irmãzinha bem que podia me ajudar que ela já tinha seis anos, mas vivia com a mão suja de terra e sem entender direito o que a gente falava". A percepção está presente na recordação de Leontina, pois a mesma está inclusa na ação, ela é a participante principal do cenário por ela evocado, isto é, seu corpo está no interior do cenário, uma vez que ela vive o fato recordado, pois a personagem faz parte do mesmo.

O corpo é, por sua vez, um dos principais instrumentos que ativa a recordação da personagem, porque uma vez que se trata de uma meretriz, o corpo é bastante enfático no comentário dela. É através dele que ela consegue seu sustento quando trabalha. Por isso, as fontes de suas lembranças envolvem momentos em que é explorada, humilhada, de modo que seu corpo é sendo a causa da situação pela qual Leontina passa. A respeito do corpo explorado e como fonte de lembranças, tem-se:

No começo pensei que ia morrer de tanta canseira. Dançava com os fregueses das dez às quatro da manhã sem parar. $E$ quando me esticava na cama era horrível porque se a cabeça dormia o pé continuava dançando sem parar (TELLES, 1985, p. 108).

Configura-se relevante o papel que o corpo desempenha no processo de rememoração da personagem, a partir de seu sofrimento físico e psíquico. O que pode ser a origem dessas recordações é justamente a carga atribuída ao corpo sobrecarregado, devido Leontina ter sido sujeita à exploração sexual, cujo fato é a causa de se voltar ao seu passado dolorido.

Mas não era apenas ela que sofria com tais atos, pode-se vislumbrar, em Confissão de Leontina, uma crítica aos abusos cometidos pelas mulheres que praticavam tal trabalho, uma vez que, como a protagonista deixa bem claro que as 
mulheres estavam sofrendo pelas péssimas condições em que se encontrava, ademais o poder patriarcal tinha domínio sobre o corpo de suas clientes e utilizavam-no a seu bel prazer.

Portanto, percebe-se, também, a memória coletiva no conto lygiano, uma vez que a protagonista remete a cenas em que não estar participando sozinha, mas acompanhada de suas colegas de trabalho. Isso porque, em certas partes de seu discurso, Leontina se vê refletindo, juntamente com as amigas, sobre as condições de vida que elas possuíam.

Sobre a memória coletiva, Halbwachs afirma que:

Para que nossa memória se aproveite da memória dos outros, não bastam que estes nos apresentem seus testemunhos: também é preciso que ela não tenha deixado de concordar com as memórias deles e que existam muitos pontos e contato entre uma e outras para que ela não tenha deixado de concordar com as memórias deles e que existam muitos pontos de contato entre umas e outras para que a lembrança que nos faz recordar venha a ser reconstruída sobre uma base comum (HALBWACHS, 2003, p. 39).

No que tange aos aspectos rememorados, a memória grupal fortalece as recordações na medida em que a comunidade se volta ao passado, recordando os pormenores dele. É preciso que haja, ainda, um acordo em que o que é visto por um indivíduo e outro para os acontecimentos possam emergir de forma singular, para a compreensão dos momentos pretéritos, bem como das impressões dos mesmos. Um determinado fato vivido por um determinado grupo, ao ser citado, precisa que se remeta a ele de forma que os detalhes, o que foi esquecido por um determinado membro, seja lembrado e completado pelo outro e, assim, o episódio terá sido recordado.

\section{CONSIDERAÇÕES FINAIS}

O conto, Confissão de Leontina trata-se da história traumática da personagem principal, Leontina. Segundo o viés da memória afirma-se que ela se utiliza da memória individual e coletiva, a fim de rememorar sua vida, mais especificamente 0 ocorrido doloroso que mudou o seu destino. 
A memória individual está presente na medida em que a protagonista se lembra de fatos que lhe vêm à mente de maneira que somente ela está no cenário, ou os registros, por ela documentados, são impressões suas.

Já a memória coletiva se origina no relato que ela faz com a inclusão das amigas de profissão, relatando as experiências por elas passadas, frente ao poder patriarcal, cuja rememoração está impregnada de imagens que fortalecem o poder de recordação das cenas.

No que se refere a teoria de Bergson (1999), mais especificamente acerca da percepção, o sociólogo afirma que esse fenômeno memorialístico é pautado no contato do corpo ao ambiente no qual está inserido, o que acarreta a recordação. Nesse sentido, corrobora-se as impressões de Leontina, ao rememorar os fatos. Destaca a percepção que tem do seu corpo em muitas cenas de sua vida, uma vez que o mesmo, em alguns fatos, é a causa de suas lembranças, isto é, as marcas que a vida lhe deixou estão impressas na memória do corpo, porque foi o receptor das impressões deixadas no passado.

Consoante esse pensamento, por meio do relato da personagem, constata-se que ela não se desliga de seu passado doloroso, de modo que se torna extensão do seu presente.

Por fim, a partir da leitura de Confissão de Leontina, pode-se constatar que, ao rememorar sua vida pretérita, é como se Leontina nunca tivesse saído do passado, os dois tempos coexistem: o passado entrelaçado no presente configurando-se uma simbiose temporal.

\section{REFERÊNCIAS}

BARTHES, Roland. A Morte do autor. Texto publicado em O Rumor da língua. São Paulo: Martins Fontes, 2004.

BERGSON, Henri. Matéria e Memória: ensaio sobe a relação do corpo com o espírito. Tradução Paulo Neres. $2^{\mathrm{a}}$ ed. São Paulo: Martins Fontes, 1999.

HALBWACHS, Maurice. A memória coletiva. Tradução de Beatriz Sindou. São Paulo: Centauro, 2003.

FREUD, Sigmund. Introdução ao narcisismo: ensaios de metapsicologia e outros textos. Trad. De Paulo César de Sousa. São Paulo: Companhia das Letras, 2010.

LE GOFF, Jacques. História e memória. Trad. Bernardo Leitão [et. al].- Campinas: 
Editora da UNICAMP, 1990.

LEVI, Pieno. Os afogados e os sobreviventes. Trad. Luiz Sérgio Henriques. Rio de Janeiro: Paz e Terra, 1990.

PAZ, Octávio. O arco e a lira. [Trad. Olga Savary]. Rio de Janeiro: Nova Fronteira, 1982.

POLLAK, Michel. Estudos Históricos. São Paulo: Editora Revista dos Tribunais, 2010.

RICOUER, Paul. A memória, a história, o esquecimento. Tradução Alan François [et.al].- Campinas: editora da Unicamp, 2007.

TELLES, Lygia Fagundes. Confissão de Leontina. In: Os melhores contos de Lygia Fagundes Telles. Seleção. Eduardo Portella.5ªedição. -São Paulo: Global, 1988. 